\title{
Aluminum tolerance on genotypes of signal grass $^{1}$
}

\author{
Gislayne de Araujo Bitencourt ${ }^{2}$, Lucimara Chiari ${ }^{3}$, Valdemir Antônio Laura ${ }^{3}$, Cacilda Borges \\ do Valle ${ }^{3}$, Liana Jank ${ }^{3}$, José Roberto Moro ${ }^{2}$
}

\footnotetext{
${ }^{1}$ Fundação de Apoio ao Desenvolvimento do Ensino, Ciência e Tecnologia do Estado de Mato Grosso do Sul - FUNDECT and Coordenação de Aperfeiçoamento de Pessoal de Nível Superior - CAPES.

2 Universidade Estadual Paulista "Júlio de Mesquita Filho" UNESP/Jaboticabal, Via de acesso Prof. Paulo Donato Castellani, s/n km 5 14884-900 - Jaboticabal, SP.

${ }^{3}$ Embrapa Gado de Corte, BR 262 km 4 - Caixa Postal 154 - 79002-970 - Campo Grande, MS.
}

ABSTRACT - The objective of this work was to evaluate aluminum tolerance of five genotypes of Urochloa decumbens (D24, CD24-2, CD24-27, CD24-45 e D62) and five genotypes of Urochloa ruziziensis (R30, R44, R46, R50 and $\mathrm{R} 125)$ in hydroponic system. Uniform tillers were collected from these genotypes and transferred to two solutions: solution 1 (200 $\mu \mathrm{M} \mathrm{CaCl}_{2}$, pH 4.2) and solution $2\left(200 \mu \mathrm{M} \mathrm{CaCl}_{2}+200 \mu \mathrm{M} \mathrm{AlCl}_{3}, \mathrm{pH} 4.2\right)$. Twenty-one days later, the roots of the plants were separated, stained and digitalized for analysis of the length and diameter of the main root. The experiment was conducted in a completely randomized design, in factorial (genotypes $\times$ doses) with three replications. A significant interaction occurred between genotype and dose for length and width of the main root, and the results presented in average, a significant difference for most genotypes. The means of main root length in the absence and presence of aluminum were not significant for D62 ( $U$. decumbens cv. Basilisk), CD24-45 and R46. Means were not significant for the diameter of the main root for CD24-2, CD24-27 and D62. Genotype D62 was the only one classified as tolerant to aluminum and R50 the only one classified as sensitive. Most evaluated genotypes showed medium to low tolerance. This classification was based on confidence intervals (IC 99\%) for the mean of the relative tolerance indices estimated for length and diameter of the main root. These results can be used in the choice of progenitors aiming at developing segregating populations for studies of inheritance and mapping of genes and/or loci related to aluminum tolerance in Urochloa.

Key Words: abiotic stresses, acid soils, forages, Urochloa decumbens, Urochloa ruziziensis

\section{Tolerância ao alumínio em genótipos de capim-braquiária}

RESUMO - O objetivo neste trabalho foi avaliar a tolerância ao alumínio de cinco genótipos de Urochloa decumbens (D24, CD24-2, CD24-27, CD24-45 e D62) e cinco de Urochloa ruziziensis (R30, R44, R46, R50 e R125) em cultivo hidropônico. Desses genótipos, foram coletados perfilhos uniformes que foram transferidos para duas soluções: solução $1\left(200 \mu \mathrm{M} \mathrm{CaCl}{ }_{2}, \mathrm{pH} 4,2\right)$ e solução $2\left(200 \mu \mathrm{M} \mathrm{CaCl}_{2}+200 \mu \mathrm{M} \mathrm{AlCl}_{3}\right.$, pH 4,2). Após 21 dias, as plantas tiveram suas raízes separadas, coradas e digitalizadas para análise do comprimento da raiz principal e do diâmetro da raiz principal. O experimento foi realizado em delineamento inteiramente casualizado, em fatorial (genótipos $\times$ doses) com três repetições. Houve interação significativa entre genótipo e dose para comprimento e diâmetro da raiz principal, cujos resultados apresentaram, na média, diferença significativa para a maioria dos genótipos. As médias de comprimento da raiz principal na ausência e na presença de alumínio não foram significativas para D62 (Urochloa decumbens cv. Basilisk), CD24-45 e R46. Para diâmetro da raiz principal, as médias não foram significativas para CD24-2, CD24-27 e D62. O genótipo D62 foi o único classificado como tolerante ao alumínio e o R50, o único sensível. A maior parte dos genótipos avaliados apresentou de média a baixa tolerância. Essa classificação foi baseada nos intervalos de confiança (IC 99\%) para a média dos índices de tolerância relativa estimados para comprimento e diâmetro da raiz principal. Esses resultados podem ser utilizados na escolha de genitores visando ao desenvolvimento de populações segregantes para estudos de herança e mapeamento de genes e/ou locos relacionados à tolerância ao alumínio em Urochloa.

Palavras-chave: estresse abiótico, forrageiras, solos ácidos, Urochloa decumbens, Urochloa ruziziensis

\section{Introduction}

Many species of tropical forage grasses are options of pastures in Brazil. Species of genus Urochloa P. Beauv. spp. (syn. Brachiaria (Trin.) Griseb. spp.) are consolidated because of their capacity of adaptation to diverse environmental conditions and pasture management (Monteiro et al., 1995). There are more than 70 million hectares of brachiaria pastures, most of them in the Brazilian savannas (Cerrados) (Rao et al., 2005), which, in general, 
present naturally low fertility soils characterized by high acidity associated to toxic metals, specially aluminum (Al) (Radambrasil, 1981).

High levels of aluminum impair the growth of roots of the plants, and when they are allied to periods of water deficiency, even in the rainy season, productivity is significantly reduced, incapacitating the growth cultivation in areas with acid soils (Lima et al., 1995). Many authors have reported that aluminum fixes phosphorous in less available forms to plants; it reduces root respiration; interferes with cell division and with the enzymes responsible for the deposition of polysaccharides in the cell wall; increases cell wall rigidity; interferes in the absorption, transport and use of some chemical elements (calcium, magnesium, phosphorous and potassium) and water; and it has the capacity of precipitating the nucleic acids (Foy et al., 1978; Taylor, 1991; Ryan et al., 1995).

The use of lime that neutralizes $\mathrm{H}^{+}$and $\mathrm{Al}^{3+}$ ions is one among many alternatives used to alleviate soil acidification. However, the application of lime to the soil surface does not solve the acidity problem in the lower layers and liming into great depths is not possible because of technical and economical issues (Echart \& Cavalli-Molina, 2001). Thus, the attainment of aluminum tolerant cultivars is of great importance for agricultural production in these soils.

Accordingly, the development of segregating populations is important in inheritance studies and mapping of genes and/or loci related to aluminum tolerance and it is useful in breeding programs. Thus, it is necessary to identify segregating genitors that have the same ploidy level, are compatible and with one sexual genitor at least inasmuch as apomixes is the predominant reproductive mode in Urochloa.

The objective of this experiment was to evaluate Urochloa spp. genotypes grown in hydroponic culture for aluminum tolerance, aiming at selection of genitors for the development of a segregating population for studies of inheritance and mapping of this characteristic in Urochloa.

\section{Material and Methods}

Ten genotypes of Urochloa, D62 (B. decumbens cv. Basilisk, apomictic and tetraploid), D24 (B. decumbens, sexual and diploid accession), CD24-2, CD24-27 and CD24-45 (B. decumbens, sexual and tetraploidized by colchicine); R124 (B. ruziziensis, sexual and diploid); R30, R44, R46 and R50 (B. ruziziensis, sexual and tetraploidized by colchicine) selected from the germplasm bank and from the breeding program at Embrapa Gado de Corte were evaluated. Genotype
D62 was used as an aluminum standard tolerant reference and R44 as an aluminum standard susceptible reference, according to Wenzl et al. (2006).

Ten tillers were harvested from these genotypes. They were rooted in pots containing previously fertilized soil (mixture of $0.2 \%$ black:red soil 1:3, 0.2\% lime, 0.02\% 0-20-20 fertilizer and $0.005 \%$ urea) and were maintained in the greenhouse. Forty-five days later, the plants were cut to stimulate tillering. After 15 days, young tillers were removed and transferred to a hydroponics table containing rooting solution prepared according to Hoagland \& Arnon (1950). This procedure was done to standardize the age of the tillers used in the hydroponic culture in the solutions with and without aluminum.

After 11 days of rooting, uniform plants were selected to be transferred in pairs to two hydroponic tables, containing different solutions: solution $1\left(200 \mu \mathrm{M} \mathrm{CaCl}_{2}, \mathrm{pH} 4.2\right)$ and solution $2\left(200 \mu \mathrm{MCaCl}_{2}+200 \mu \mathrm{M} \mathrm{AlCl}_{3}, \mathrm{pH} 4.2\right)$, according to the methodology proposed by Wenzl et al. (2006). The pH of these solutions were monitored daily during 21 days and, whenever necessary, adjusted by adding $10 \% \mathrm{HCl} 10 \%$ or $20 \% \mathrm{NaOH}$. Twenty liters of each solution were used and the volume was corrected by the addition of distilled water whenever it had decreased $0.5 \mathrm{~L}$.

After this period, the roots of the plants were separated and stained in $0.1 \%$ methylane blue and neutral red solution for 24 hours. They were then washed with distilled water and the images were obtained with a light scanner (HP Photosmart 1200), with an image resolution of $300 \mathrm{dpi}$, to evaluate the length and diameter of the main root of the plants in the solutions 1 and 2. For this, the program Image J, available at <http://rsbweb.nih.gov/ij/ index.html>, was used.

A completely randomized design was used, in a $10 \times 2$ factorial, composed of 10 genotypes and two aluminum doses, and three replications, to identify the simple effects of aluminum doses, the genotype, and the interaction genotype $\times$ aluminum doses. The main root length and diameter of each genotype in the presence and absence of aluminum were compared by Tukey test at a $1 \%$ significance level.

The percentage root growth inhibition (ICR) was estimated for the length of the main root as follows: ICR = $[1-(\mathrm{CR}+\mathrm{Al} / \mathrm{CR}-\mathrm{Al})] \times 100$ (Horst et al., 1997). The same thing was done with the data on main root diameter to estimate the percentage of thickening of the diameter of the roots $(\mathrm{EDR}): \mathrm{EDR}=[1-(\mathrm{DR}+\mathrm{Al} / \mathrm{DR}-\mathrm{Al}] \times 100$.

To compare the results related to length and diameter of the main root, the aluminum tolerance index was also 
estimated, according to Furlani \& Furlani (1991), for these characteristics. The genotypes were classified as tolerant, intermediate and susceptible to aluminum based on confidence intervals of $99 \%$ obtained for the tolerance indices for length and diameter of the roots.

\section{Results and Discussion}

Identification of the existence of significant interaction $(\mathrm{P} \leq 0.01)$ between genotype and doses of aluminum for the two variables analyzed, length and diameter of the main root was done by ANOVA. Furthermore, significant differences were detected for these two variables, both between aluminum doses and among genotypes (Table 1).

Length and diameter of the main root changed with the addition of aluminum to the solution. These results corroborate with reports in the literature in which the aluminum phytotoxicity is a phenomenon that influences the apical meristem of the roots and the cell elongation region, inhibiting mitosis, with immediate reflections in the root system (Almeida et al., 2000).

The significant interaction $(\mathrm{P} \leq 0.01)$ for the two variables indicated dependency between genotype and aluminum doses. Therefore, it was important to evaluate the performance of each genotype by their mean comparisons. Differences were found for most of the analyzed genotypes $(\mathrm{P} \leq 0.01)$, for the means of the main root length in the solutions with and without aluminum, except for $U$. decumbens CD24-45, U. decumbens D62 and U. ruziziensis R46 (Figure 1).

The percentage of root growth inhibition was calculated for all genotypes. The lowest value of root growth inhibition (6.93\%) was observed for the standard tolerance reference, genotype D62. Research by Wenzl et al. $(2001,2002)$ had already shown this cultivar to be the most aluminum tolerant genotype in comparison to other genotypes of the genus Urochloa and also to other grasses as wheat, triticale and maize. On the other hand, the highest root growth inhibition (59.9\%) was observed for U. ruziziensis genotype R50.
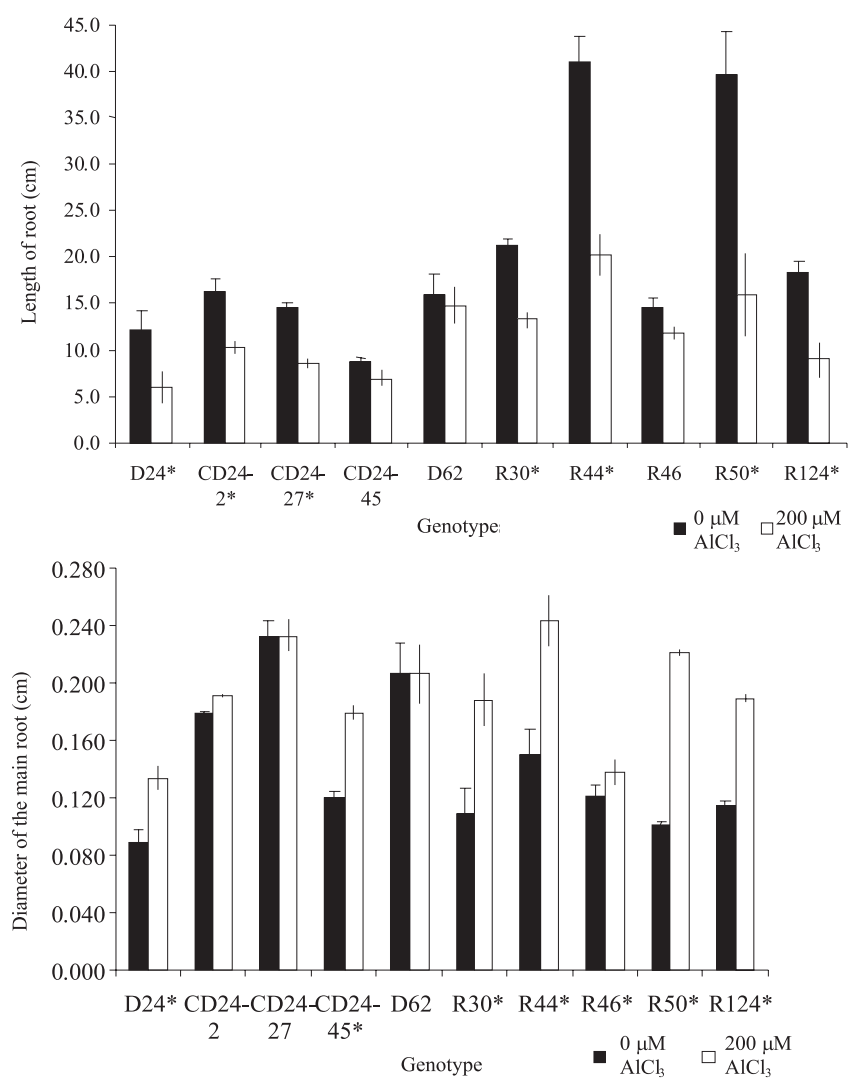

*Significant by the Tukey test $(\mathrm{P} \leq 0.01)$.

Figure 1 - Length and diameter of the main root of ten genotypes of Urochloa grown in solutions with and without aluminum.

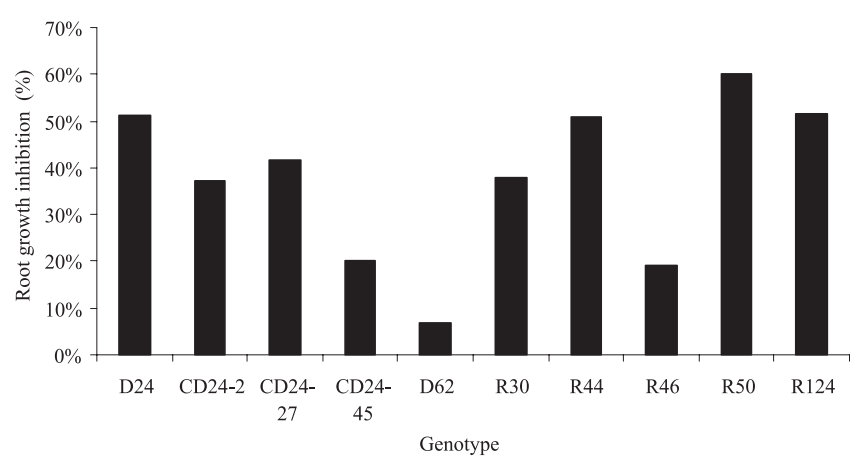

Figure 2 - Root growth inhibition, in percentage, of the ten genotypes of Urochloa grown in aluminum solution.

Table 1 - Summary of the analysis of variance for main root length and diameter in ten genotypes evaluated in the solutions with and without aluminum

\begin{tabular}{|c|c|c|c|}
\hline Sources of variation & Degrees of freedom & Length of the main root & Diameter of the main root \\
\hline Aluminum doses & 1 & $275.5277^{*}$ & $362.0613^{*}$ \\
\hline Genotype & 9 & $83.8009 *$ & $79.9127 *$ \\
\hline Genotype $\times$ dose & 9 & $22.1392 *$ & $25.3549 *$ \\
\hline Residue & 40 & & \\
\hline Overall mean & & 15.9450 & 0.1674 \\
\hline Standard deviation & & 2.0120 & 0.0102 \\
\hline CV (\%) & & 12.62 & 6.09 \\
\hline
\end{tabular}

$\mathrm{CV}=$ coefficient of variation; *Significant by the $\mathrm{F}$ test $(\mathrm{P} \leq 0.01)$. 
The remaining genotypes presented a root growth inhibition from 19.2 to $51.4 \%$ (Figure 2).

The evaluated genotypes presented distinct levels of aluminum tolerance and sensitivity. The variability of aluminum toxicity tolerance had already been observed in another forage species, Panicum maximum, by Almeida et al. (2000) and Oliveira et al. (2000). Those authors reported differences in the growth of the main root of genotypes grown in solutions with and without aluminum.

Root growth inhibition is considered to be the prime consequence of aluminum toxicity, resulting in a smaller volume of soil explored by the plant, consequently reducing its mineral nutrition and water absorption. Root growth inhibition occurs mainly because of the harmful action of aluminum that reduces cell membrane permeability and binds to the phosphate groups of the deoxyribonucleic acid decreasing replication and transcription activity (Faquin, 1997; Malavolta et al., 1997).

According to data on the main root length, roots of $U$. ruziziensis genotypes were longer than roots of $U$. decumbens genotypes because of the differences in the root establishment time between species inasmuch as $U$. ruziziensis was the first one to establish roots. In another study with $U$. decumbens $\mathrm{cv}$. Basilisk and $U$. brizantha cv. Marandu treated with ANA (naphtalene acetic acid), a low rate of rooting induction was found for cultivar Basilisk in comparison to Marandu (Dutra et al., 2005). The decumbent characteristic of $U$. decumbens partly justifies this variation because the plant does not have many reserves in the tillers and it produces fewer and smaller roots. Thus, the genotypes of these two species cannot be compared, which led to comparisons within each genotype.

In the analysis of the main root diameter, the means for the ten genotypes in the solutions with and without aluminum differed $(\mathrm{P} \leq 0.01)$ in seven of them: $\mathrm{D} 24, \mathrm{CD} 24-45$, R30, R44, R46, R50 and R124. The genotypes CD24-2, CD24-27 and D62 did not present significant differences (Figure 1).

Root diameter thickening was calculated and percentages varying from 0 to $119.2 \%$ were obtained, suggesting that the response for this characteristic was much more perceivable than for main root length. The genotype with the lowest value of root thickening was the standard tolerance reference (D62). For the remaining $U$. decumbens genotypes, root thickening varied from 0.29 to $50 \%$, while for the $U$. ruziziensis genotypes, the values varied from $14.6 \%$ to $119.2 \%$ (Figure 3 ). In the cell, aluminum alters the properties of the walls and of the plasmalemma inasmuch as it affects the nutrient carrier system, and inhibits cell elongation of the main axis, thickening the

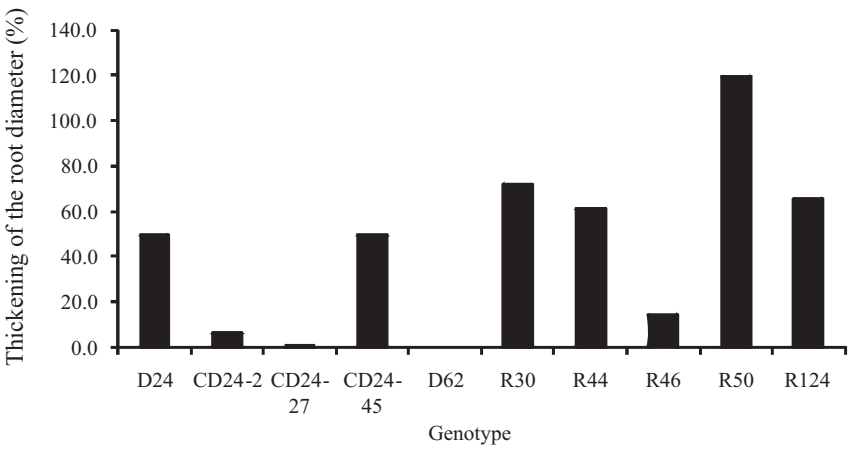

Figure 3 - Thickening of the root diameter, in percentage, of the ten genotypes of Urochloa grown in solution containing aluminum.

roots and making them less functional (Ryan et al., 1993; Kochian, 1995).

According to Furlani \& Furlani (1991), genotypes with tolerance indices larger than the confidence interval may be considered as tolerant, whereas those with smaller values may be classified as sensitive, and those with values between the maximum and the minimum limits were considered as intermediate. The mean and the confidence interval of the aluminum tolerance index for root length were 2.2 and 0.9 to 3.5 , respectively. Accordingly, the genotypes classified as tolerant were CD24-45, D62 and R46; as moderately tolerant were CD24, CD24-2, CD24-27, R30, R44 and R124; and the only genotype classified as sensitive was R50. The results of root diameter tolerance index were different. The mean and the confidence intervals were 2.1 and 0.1 to 4.2 , respectively. The tolerant genotypes were CD24-2, CD24-27 and D62; the moderately tolerant ones were CD24, CD24-45, R30, R44, R46 and R124; and, again, the only genotype classified as sensitive was R50 (Table 2).

According to Sivaguru \& Paliwal (1993), genotypes of the same species may perform differently for aluminum, both in pots and in the field. According to the aluminum tolerance indices for root length and diameter (Table 2), the genotypes classified equally by the two indices were united in the same group: tolerant (D62), intermediates (CD24, CD24-2, CD24-27, CD24-45, R30, R44, R46 and R124) and sensitive (R50).

Although genotypes CD24, R30, R44 and R124 were classified as intermediate for aluminum tolerance by the index data, they presented significant differences when subjected to aluminum stress, both for root length and diameter. The same happened for CD24-2, CD24-27, CD24-45 and R46. Considering the results of root length and diameter, these genotypes could be classified in 
Table 2 - Indices of relative tolerance of main root length and diameter and classification of the genotypes to aluminum tolerance

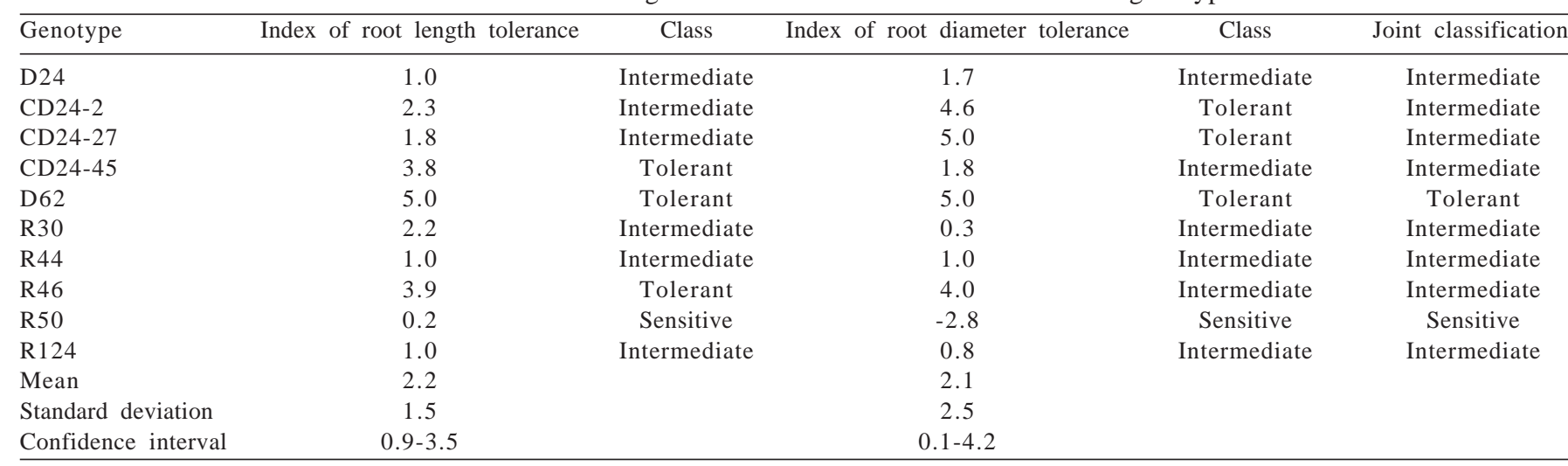

two levels of intermediate tolerance: mean tolerance (CD24-2, CD24-27, CD24-45 and R46) and low tolerance (CD24, R30, R44 and R124).

These results are relevant on choosing genitors for the development of segregating populations for aluminum tolerance, which is useful for inheritance studies and for the mapping of genes and/or loci for this characteristic. Assisted selection may help the breeder in breeding programs of the genus Urochloa.

Many methodologies are used to select aluminum tolerant genotypes in solutions and controlled environments, most of them using seedlings grown in nutritive solution. In aluminum toxicity studies on grasses, Papernik \& Kochian (1997) and Almeida et al. (2000) used plants cultivated in containers with nutritive solution. Miyazawa et al. (1993), on the other hand, immersed soils from eight Brazilian locations in distilled water, and extracted the solution which received different concentrations of types of toxic aluminum, determined by a potentiometer with fluoride selective electrode. In this study, it was used the method described by Wenzl et al. (2006), which used tillers, so it can be perfectly applied to the hybrids in a segregating population. This method was efficient for both of variables, root length and diameter.

Based on this methodology and on the studied genotypes, it is suggested to use D62 (U. decumbens cv. Basilisk - apomictic and tetraploid), aluminum tolerant, as a male genitor, and R50 (sexual clone of U. ruziziensis, tetraploidized by colchicine), the most sensitive to aluminum, as the female genitor. Two diploid sexual genotypes, D24 and R124, were also analyzed because they would be excellent options for mapping. However, both were intermediate and with low aluminum tolerance, therefore, this possibility may be discarded.

\section{Conclusions}

The studied genotypes show variability in the aluminum tolerance, indicating feasibility for genetic breeding of Urochloa for better adaptation to acid soils. Most analyzed genotypes present medium to low aluminum tolerance. Only the genotype $U$. decumbens $\mathrm{cv}$. Basilisk is aluminum tolerant. Among the analyzed genotypes, $U$. ruziziensis $\mathrm{R} 50$ is the only one to show response to aluminum. The results can be used for choosing genitors aiming at developing a segregating population for inheritance studies and mapping of genes and/or loci related to aluminum tolerance in Urochloa.

\section{References}

ALMEIDA, A.A.S.; MONTEIRO, F.A.; JANK, L. Avaliação de Panicum maximum Jacq. Para tolerância ao alumínio em solução nutritiva. Revista Brasileira de Ciência do Solo, v.24, p.339-344, 2000

DUTRA, J.D.; LAURA, V.A.; FAVERO, S. Indução de raízes adventícias em Brachiaria brizantha cv. marandu e Brachiaria decumbens cv. Basilisk, por auxinas (AIB e ANA). In: ARRUDA, C.C.P.; DOURADO, D.M.; ILHA, I.N. et al. (Orgs.). Bioinformação. Campo Grande: Editora da UNIDERP, 2005. p.367-378.

ECHART, C.L.; CAVALLI-MOLINA, S. Fitotoxidade do alumínio: efeitos, mecanismos de tolerância e seu controle genético. Ciência Rural, v.31, p.531-541, 2001.

FAQUIN, V. Nutrição mineral de plantas. Lavras: UFLA/FAEPE, 1997. 227p.

FOY, C.D.; CHANEY, R.L.; WHITE, M.C. The physiology of metal toxicity in plants. Annual Review of Plant Physiology, v.29, p.511-566, 1978.

FURLANI, P.R.; FURLANI, A.M.C. Tolerância a alumínio e eficiência a fósforo em milho e arroz: características independentes. Bragantia, v.50, p.331-340, 1991.

HOAGLAND, D.R.; ARNON, D.I. The water-cultured method for growing plants without soil. Berkeley, CA: California Agricultural Experiment Station, 1950. p.1-32 (Circular, 347).

HORST, W.J.; PÜSCHEL, A.K.; SCHMOHL, N. Induction of callose formation is a sensitive marker for genotypic aluminum sensitivity in maize. Plant Soil, v.192, p.23-30, 1997. 
KOCHIAN, L.V. Cellular mechanisms of aluminum toxicity and resistance in plants. Annual Review of Plant Physiology and Plant Molecular Biology, v.46, p.237-260, 1995.

LIMA, M.; MIRANDA-FILHO, J.B.; FURLANI, P.R. Diallel cross among inbred lines of maize differing in aluminum tolerance. Revista Brasileira de Genética, v.18, n.4, p.579-584, 1995.

MALAVOLTA, E.; VITTI, G.C.; OLIVEIRA, S.A. Avaliação do estado nutricional das plantas. 2.ed. Piracicaba: POTAFOS, 1997. 319p.

MIYAZAWA, M.; CHIERICE, G.O.; PAVAN, M.A. Determinação de alumínio tóxico às raízes do trigo por potenciometria com eletrodo seletivo de fluoreto. Pesquisa Agropecuária Brasileira, v.28, p.955-61, 1993.

MONTEIRO. F.A.; RAMOS, A.K.B.; DE CARVALHO, D.D. et al. Cultivo de Brachiaria brizantha Stapf. cv. Marandu em solução nutritiva com omissões de macronutrientes. Scientia Agricola, v.52, n.1, p.135-141, 1995.

OLIVEIRA, A.C.; FILHO, J.A.U.; SIQUEIRA, W.J. Nova metodologia de avaliação da reação de genótipos de capimcolonião ao alumínio. Pesquisa Agropecuária Brasileira, v.35, n.11, p.2261-2268, 2000.

PAPERNIK, L.A.; KOCHIAN, L.V. Possible involvement of Alinduced electrical signal in Al tolerance in wheat. Plant Physiology, v.115, p.657-667, 1997.

RADAMBRASIL. Levantamento de recursos naturais. Rio de Janeiro: Ministério das Minas e Energia, 1981. 640p. v.25, folha SD-22 Goiás.

RAO, I.; WENZL, P.; ARANGO, A. et al. Advances in developing screening methods and improving aluminum resistance in common bean and Brachiaria. In: WORKSHOP ON ADVANCES IN IMPROVING ACID SOIL ADAPTATION OF TROPICAL CROPS AND FORAGES AND MANAGEMENT OF ACID SOILS, 2005, Brasília. Anais... Brasília, 2005. p.7-10.

RYAN, P.R.; DITOMASE, J.M.; KOCHIAN, L.V. Aluminum toxicity in roots: an investigation of spatial sensitivity and the role of the root cap. Journal of Experimental Botany, v.44, p.437-446, 1993.

RYAN, P.R.; SHAFF, J.E.; KOCHIAN, L.V. Aluminum toxicity in roots: correlation among ionic currents, ion fluxes, and rot elongation in aluminum-sensitive and aluminum-tolerant wheat cultivars. Plant Physiology, v.99, p.1193-1200, 1995.

SIVAGURU, M.; PALIWAL, K. Differential aluminum tolerance in some tropical rice cultivars. I. Growth performance. Journal of Plant Nutrition, v.16, n.9, p.1705-1716, 1993.

TAYLOR, G.J. The physiology of aluminum tolerance in higher plants. Communication in Soil Science and Plants Analysis, v.19, p.1179-1194, 1991.

WENZL, P.; PATIÑO, G.M.; CHAVES, A.L. et al. The high level of aluminum resistance in signalgrass is not associated with known mechanisms of external aluminum detoxification in root apices. Plant Physiology, v.125, n.3, p.1473-1484, 2001.

WENZL, P.; CHAVES, A.L.; PATIÑO, G.M. et al. Aluminum stress stimulates the accumulation of organic acids in root apices of Brachiaria species. Journal Plant Nutrition and Soil Science, v.165, n.5, p.582-588, 2002.

WENZL, P.; ARANGO, A.; CHAVES, A.L. et al. A greenhouse method to screen Brachiaria grass genotypes for aluminum resistance and root vigor. Crop Science, v.46, n.2, p.968-973, 2006. 